\title{
Hemophilia A: an ideal disease to correct in utero
}

\author{
Christopher D. Porada, Christopher Rodman, Glicerio Ignacio, Anthony Atala and \\ Graça Almeida-Porada*
}

Regenerative Medicine, Wake Forest Institute for Regenerative Medicine, Winston-Salem, NC, USA

\section{Edited by:}

Rob Gourdie, Virginia Tech Carilion

Research Institute, USA

\section{Reviewed by:}

Robert Gros, Robarts Research

Institute, Canada

Sarkis Derderian, Emory University, USA

\section{*Correspondence:}

Graça Almeida-Porada, Regenerative Medicine, Wake Forest Institute for Regenerative Medicine, Richard H. Dean Biomedical Building, 391 Technology Way, Winston-Salem, NC 27157-1083, USA

e-mail:galmeida@wakehealth.edu
Hemophilia $A(H A)$ is the most frequent inheritable defect of the coagulation proteins. The current standard of care for patients with HA is prophylactic factor infusion, which is comprised of regular (2-3 times per week) intravenous infusions of recombinant or plasma-derived FVIII to maintain hemostasis. While this treatment has greatly increased the quality of life and lengthened the life expectancy for many HA patients, its high cost, the need for lifelong infusions, and the fact that it is unavailable to roughly $75 \%$ of the world's HA patients make this type of treatment far from ideal. In addition, this lifesaving therapy suffers from a high risk of treatment failure due to immune response to the infused FVIII. There is thus a need for novel treatments, such as those using stem cells and/or gene therapy, which have the potential to mediate long-term correction or permanent cure following a single intervention. In the present review, we discuss the clinical feasibility and unique advantages that an in utero approach to treating HA could offer, placing special emphasis on a new sheep model of HA we have developed and on the use of mesenchymal stromal cells (MSC) as cellular vehicles for delivering the FVIII gene.

Keywords: hemophilia, in utero transplantation, in utero gene therapy, fetal intervention, immune tolerance, mesenchymal stromal cells, sheep model

\section{HEMOPHILIA A AND THE NEED FOR BETTER TREATMENTS}

Hemophilia A (HA) is the most commonly occurring inheritable deficiency of coagulation (Mannucci and Tuddenham, 2001). While the clinical severity of HA (based on FVIII plasma levels) can vary, up to $70 \%$ of patients with HA present with a severe, lifethreatening phenotype, due to having less than $1 \%$ of the normal plasma levels of FVIII activity (Kay and High, 1999; High, 2003; Agaliotis et al., 2006). These patients suffer frequent spontaneous hemorrhaging, which leads to hematomas, chronic painful and debilitating arthropathies, and potentially life-threatening internal bleeding (Agaliotis et al., 2006). The current standard of care for HA is prophylactic factor infusion, which is comprised of regular (2-3 times per week) intravenous infusions of recombinant or plasma-derived FVIII to maintain hemostasis. While the availability of this protein-based treatment has greatly improved the quality of life and extended the life expectancy for many patients with HA, it is far from and ideal therapy. Patients are sentenced to a lifetime of multiple intravenous infusions each week, and are financially strapped with treatment costs that can exceed $\$ 300,000 /$ year. Even among the $\sim 25 \%$ of HA patients worldwide who are fortunate enough to have access to FVIII prophylaxis, approximately $30 \%$ will mount an immune response to the infused FVIII, forming inhibitory antibodies (inhibitors) to FVIII (Kaveri et al., 2007). In the best case scenario, these inhibitors simply reduce the effectiveness of subsequent infusions of FVIII; in the worst case scenario, they can lead to treatment failure, precluding restoration of hemostasis and putting the patient at risk of a life-threatening bleed. These significant shortcomings highlight the urgent unmet need for novel therapies that could promise longer-lasting correction, or permanent cure, of HA.

In contrast to current protein-based therapeutics, a single gene therapy treatment could promise lifelong improvement or permanent cure of HA; indeed, several aspects of HA make it an ideal target disease for correction by gene therapy (Lipshutz et al., 1999; Arruda, 2006; Ponder, 2006; Doering et al., 2007, 2009; Ide et al., 2007; Shi et al., 2008; Nichols et al., 2009; Tellez et al., 2010; High, 2011). First, FVIII, unlike the proteins that are missing/defective in many other genetic diseases, does not need to be expressed in either a specific tissue or cell type to produce a therapeutic effect. Although the majority of FVIII produced within the body is thought to be synthesized within the liver (Fahs et al., 2014), as long as FVIII is produced by cells that are close enough to the vasculature to secrete the synthesized FVIII into the circulation, FVIII can exert its appropriate clotting activity. Second, even if FVIII levels could be restored to only $3-5 \%$ of normal, this seemingly minimal change would be predicted to exert a marked clinical improvement and greatly improve the quality of life of patients with severe HA, since it would convert these patients to a moderate/mild phenotype. Conversely, even FVIII levels as high as $150 \%$ of normal should be safe. As such, FVIII has a very wide therapeutic window (Kay and High, 1999). Armed with this knowledge, the hemophilias were among the most promising, "Target 10," group of diseases in the roadmap the American Society of Gene and Cell Therapy (www.ASGCT.org) recently provided to NIH director, Dr. Francis Collins. 


\section{SHEEP AS A PRECLINICAL MODEL OF HEMOPHILIA A}

A number of animal models have been developed to evaluate new methods of treating coagulation disorders, and also for preventing and devising way to overcome inhibitor formation. Fortunately, colonies of HA dogs in which spontaneous mutations occurred within the FVIII gene (Hough et al., 2002; Lozier et al., 2002) and FVIII-deficient mice produced via gene targeting/knockout (Bi et al., 1995) are both available to study the biology of FVIII and to begin developing/exploring gene-based strategies for treating HA. Pronounced therapeutic benefit has been demonstrated in multiple studies in the murine models (Gallo-Penn et al., 1999; Garcia-Martin et al., 2002; Reddy et al., 2002; Moayeri et al., 2004, 2005; Sarkar et al., 2004; Doering et al., 2007; Ide et al., 2007, 2010). Phenotypic correction has also been achieved in dogs with $\mathrm{HA}$, but correction in this more clinically predictive model has proven to be much more difficult than in mice (Gallo-Penn et al., 2001; Scallan et al., 2003). However, despite the promising results that have been obtained in both these models, no clinical benefit has yet been seen in any of the clinical gene therapy trials that have been conducted to-date in human patients with HA. This is in striking contrast to the recent successes that have been reported in clinical gene therapy trials treating patients with hemophilia $\mathrm{B}$ (HB) (Nathwani et al., 2011); the reasons for the marked difference in the ability of gene therapy to correct HA vs. HB are not, at present, clear. Nevertheless, as a result of the disappointing outcomes thus far, no active clinical trials are currently ongoing in which gene therapy is being used to treat HA. This is especially vexing when one considers that roughly $80 \%$ of all hemophilia cases are HA.

The difficulties seen thus far translating success in animal models into therapeutic benefit in human patients highlight the importance of preclinical animal models that both precisely mimic the disease process of HA, and closely parallel normal human immunology and physiology. To this end, we used a variety of reproductive technologies to successfully re-establish a line of sheep (Bormann et al., 2006, 2007; Almeida-Porada et al., 2007; Sanada et al., 2008; Porada et al., 2010), originally described by investigators at the Swiss Federal Institute of Technology (Neuenschwander et al., 1992; Backfisch et al., 1994; Neuenschwander and Pliska, 1994), that possess a spontaneous mutation causing severe HA, which, if not treated immediately at birth, is fatal within the first hours/days of life. Upon re-establishing this line, we fully characterized the clinical parameters of this new model (Bormann et al., 2006, 2007; AlmeidaPorada et al., 2007; Sanada et al., 2008; Porada et al., 2010). All 10 affected animals born thus far have presented with prolonged umbilical cord bleeding, protracted nail (hoof) cuticle bleeding time, bleeding following routine tail docking, and they have all experienced multiple spontaneous episodes of severe bleeding, including muscle hematomas, hematuria, and hemarthroses, all of which have promptly responded to infusion of human FVIII. Since aPTT can be fairly inaccurate when FVIII levels are very low, we had our collaborators at the BloodCenter of Wisconsin and at Emory University independently run a highly sensitive chromogenic assay to accurately quantitate the level of FVIII activity present in the circulation of these animals. The results of these assays quickly explained the severe, life-threatening phenotype we observed in this line of sheep, as FVIII activity was undetectable. Just like human patients with severe HA, these sheep experience frequent spontaneous bleeds into their "knees," which, over time, produce crippling arthropathies that ultimately lead to decreased movement, difficulties walking, and eventually symptoms of pain even just to stand up. These recurring spontaneous joint bleeds make this line of sheep unique among animal models of HA. Also in similarity to human patients, some of these sheep developed inhibitors following administration of FVIII. However, since we were restricted to treatment with human FVIII (we had not yet cloned and sequenced ovine FVIII), it is not yet clear whether these animals will also make inhibitors to the ovine protein. An ongoing collaboration with investigators at Emory University has recently resulted in the successful cloning and large scale production of recombinant B domain-deleted ovine FVIII (Zakas et al., 2012), making it possible to address this important question and to construct gene therapy vectors encoding the native ovine sequence for testing in this valuable model.

In addition to studying the clinical picture of these animals, we also sequenced the entire coding region of the ovine FVIII gene to define the precise molecular basis for their disease. This knowledge of the nature of the disease-causing mutation enabled us to then design a PCR-based RFLP that allows us to unequivocally identify affected animals at birth and even in utero, using amniotic fluid-derived cells (Bormann et al., 2006, 2007; Almeida-Porada et al., 2007; Sanada et al., 2008; Porada et al., 2010). These studies revealed that HA in this line of sheep is caused by a frame shift mutation that introduces a premature stop codon part way through the FVIII coding region. Importantly, this type of mutation has also been reported in many human HA patients (Park et al., 2004). Since this line of sheep is, to our knowledge, the only animal model of HA yet described that possesses this type of mutation, these sheep provide a unique system in which to study therapies in this context.

While another large animal model of HA would already be of value, and the nature of the mutation present in these sheep makes them unique as an HA model, sheep possess many characteristics that make them an ideal preclinical model for gene therapy, especially in the context of HA. Firstly, sheep share many important physiological and developmental characteristics with humans. As a result, they have been used extensively in the study of mammalian fetal physiology, and the results obtained with this model have been directly applicable to the understanding of human fetal growth and development (Jeanblanc et al., 2014). In contrast to dogs, pigs, and many other large animals which tend to have large litters of offspring, sheep, like humans, typically give birth to only one or two offspring in each pregnancy. Secondly, sheep are similar in size/weight to humans, both at birth and as adults, making it possible to develop and test clinically relevant doses of vector/cells directly in this model prior to translating to the clinical arena. Thirdly, the development of the immune system during fetal ontogeny has been thoroughly delineated in sheep (Silverstein et al., 1966; Sawyer et al., 1978; Osburn, 1981; Tuboly et al., 1984; Maddox et al., 1987a,b,c), making this model ideal for investigating the immune facets of treating HA via gene therapy. An additional unique advantage to using sheep to study HA treatment is that in sheep, like human, the majority 
of the FVIII carrier protein, vWF, is stored/located within their platelets. This is in contrast to dog, in which vWF circulates free in plasma (McCarroll et al., 1988; Parker et al., 1991). This key difference makes the sheep the most clinically relevant large animal model in which to test the efficacy of platelet-targeted gene therapy approaches for treating HA (Shi et al., 2006, 2008; Shi and Montgomery, 2010; Montgomery and Shi, 2012). For these collective reasons, we feel that sheep are an especially fitting model in which to develop and test gene therapy treatments for HA.

\section{FEASIBILITY AND JUSTIFICATION FOR TREATING HA PRIOR TO BIRTH}

Even if FVIII costs were reduced to the point that most HA patients could afford prophylaxis, these patients would still require recurrent, intravenous infusions throughout their lives, and still have a significant risk of treatment failure due to inhibitor induction. These problems, as well as many of the obstacles that have precluded gene therapy from curing patients with HA (and many other diseases) to-date, could likely be overcome/eliminated by performing gene therapy prior to birth. At the present time, HA can be diagnosed relatively early in gestation (10-12 weeks), just like many other genetic diseases. The ability to diagnose HA early in development makes it feasible to begin devising methods to try to correct this disease prior to birth. Fetal transfusions and in utero stem cell-based therapies have safely been performed clinically for decades (Flake and Zanjani, 1999; Troeger et al., 2006). Indeed, to date, 46 in utero transplants have been performed in human patients (Tiblad and Westgren, 2008; Tarantal and Lee, 2010), for 14 different genetic disorders, including 1 case of HA (Troeger et al., 2006; Touraine, 2013). These studies have collectively provided unassailable proof that the early human fetus can be accessed multiple times with an extremely low procedure-related risk, assuming that a minimally invasive, ultrasound guided approach is employed (Flake et al., 1996; Flake and Zanjani, 1999; Tarantal et al., 2006; Troeger et al., 2006; Merianos et al., 2008; Roybal et al., 2010; Tarantal and Lee, 2010). It is important to note that it was studies performed in the fetal sheep model that provided the experience and knowledge that led to the first curative in utero transplant in a human patient (Flake et al., 1996), emphasizing the value and importance of the fetal sheep model for developing clinically viable approaches to therapy, and for predicting clinical outcome. Using these established, clinically proven methods to deliver a corrective FVIII gene early in gestation could cure HA in utero, enabling the birth of a normal healthy baby requiring no further treatments. Such a treatment, if successful, would clearly represent a major advance, both from an economic standpoint (one treatment rather than a lifetime of expensive treatments several times each week), and with respect to the quality of life of the patient.

While most individuals with a family history of HA are encouraged to have prenatal screening ( $\sim 70-75 \%$ of new HA cases arise in families with a history of HA), parents presented with a prenatal diagnosis of HA currently have only 2 possible choices: pregnancy termination or the birth of a child with HA. The availability of a safe and effective in utero treatment would provide parents a much-needed 3rd option, which would certainly provide the needed impetus for much more widespread prenatal HA screening. In contrast to in vitro embryo screening and selection, which has been proposed as a possible solution in families with a history of HA and other genetic diseases, in utero gene therapy requires only minimal equipment that would already be in place for prenatal diagnosis, and should not be prohibitively expensive. Several recent studies have provided conclusive evidence that prenatal screening for the hemophilias can be cost-effective, even when considering developing third world countries (Klein et al., 2001; Sasanakul et al., 2003; Peyvandi, 2005). Moreover, another recent study has shown it is now possible to diagnose HA in utero by performing digital PCR on the small number of fetal cells present within the mother's peripheral blood, making it possible to diagnose HA prenatally with essentially zero risk to the fetus or mother (Tsui et al., 2011).

Although the clinical and financial advantages of in utero gene therapy are compelling, in and of themselves, it is important to realize that there are also features of the fetus that make it a better gene therapy recipient than the adult (Matzinger, 2002; Porada et al., 2004a,b). For instance, cell populations that are quiescent in the adult, and largely refractory to transduction with many commonly employed viral vectors, are actively cycling in the fetus and amenable to transduction at relatively high efficiencies. For example, we showed that a single intraperitoneal injection of a small volume of $\gamma$-retroviral vector resulted in gene transfer levels within the hematopoietic system of 5-6\% (Porada et al., 1998, 2001a, 2002a; Tran et al., 2000); levels that would undoubtedly be beneficial in HA. Further studies involving antibody selection of CD34 ${ }^{+}$cells and serial transplantation/repopulation (Porada et al., 1998, 2008; Tran et al., 2000), provided compelling evidence that this approach successfully modified bona fide hematopoietic stem cells, indicating this method could provide lifelong disease correction.

Our results also demonstrated that this approach successfully transduced hepatocytes and hepatic endothelium at levels that could well be therapeutic in HA, and defined the temporal window during gestation for optimal transduction of these cells within the liver (Porada et al., 2005a). Concurrently, fetal gene delivery experiments conducted in sheep, rodent, and nonhuman primate models, by other investigators who employed a variety of viral-based vectors, produced similar results (Porada et al., 1998, 2002b, 2004a, 2005a,b; Lipshutz et al., 1999, 2000; Schneider et al., 1999, 2002; Themis et al., 1999; Tarantal et al., 2001a,b,c, 2005, 2006; David et al., 2003; Waddington et al., 2003, 2004; Chen et al., 2004a; Jimenez et al., 2005; Lee et al., 2005; Park et al., 2009; Tarantal and Lee, 2010). The collective results of these studies clearly support the ability of this method to deliver a FVIII transgene to the nascent liver with sufficient efficiency to convert severe HA patients to a moderate or, perhaps, even mild phenotype (Porada et al., 2005a).

While the active cell cycling in the fetus enables efficient transduction with vectors that require mitosis, it is important to note that this ongoing proliferation in all of the fetal organs is also of benefit when using vectors that do not have an absolute requirement for mitosis. Gene delivery early in gestation, regardless of the vector employed, also makes it possible to achieve subsequent expansion of these gene-corrected cells throughout the rest of gestation. As such, even if the initial gene transfer only transduces a 
small number of the desired target cells, this subsequent expansion could produce clinically useful levels of gene-correction by birth.

As mentioned earlier, one of the biggest obstacles/drawbacks to treating severe HA by repeated infusion of purified or recombinant FVIII protein is the formation of inhibitory antibodies in $\sim 30 \%$ of patients. It is important to note that there are also distinct immunologic benefits to performing gene therapy in the developing fetus. Early in immunologic development, before thymic processing of mature lymphocytes, the fetus appears to be highly receptive to foreign antigens. Indeed, exposure to foreign antigens during this period often results in sustained tolerance, which can become permanent if the presence of the antigen is maintained (Billingham et al., 1954). We have spent the last two decades performing in utero gene transfer studies in the sheep model (Porada et al., 1998, 2001a,b, 2004a, 2005a; Tran et al., 2000; Park et al., 2003a,b, 2004), and have shown that it is possible to take advantage of this unique temporal window of immunonaïveté to deliver exogenous genes during this period of gestation and induce durable tolerance to the vector-encoded gene product (Tran et al., 2001). This tolerance induction appears to involve both cellular and humoral mechanisms, since antibody and cellular responses to the transgene product were both significantly diminished in these animals, even several years after fetal gene transfer. Indeed, further mechanistic studies demonstrated that gene delivery early in fetal development exploits several central and peripheral tolerogenic avenues that exist in the fetus (Colletti et al., 2008). These results strongly imply that fetal gene therapy, even if it does not cure HA, would still be an ideal treatment modality for this disease, since permanent immune tolerance to FVIII could be induced. This would thus ensure that postnatal therapy, be it protein- or gene-based, could proceed safely without any of the immune-related problems that currently plague HA treatment.

To-date, the only experimental studies to directly investigate fetal gene therapy for the treatment of the hemophilias have targeted hemophilia B (factor IX deficiency) (Lipshutz et al., 1999; Schneider et al., 1999, 2002; Themis et al., 1999; David et al., 2003, 2011; Waddington et al., 2003, 2004; Chen et al., 2004a; Mattar et al., 2011). This is most likely a result of the greater ease with which FIX can be cloned into a variety of viral vectors, and efficiently expressed upon transduction of appropriate target cells; this is in marked contrast to the difficulties that were initially seen when attempting to express FVIII in the context of viral vectors (Ponder, 2011). Because HA patients have at least a tenfold higher likelihood of developing inhibitors than hemophilia $B$ patients (Ehrenforth et al., 1992; Chitlur et al., 2009), these studies, while encouraging, leave unanswered the critical question of whether fetal gene delivery's ability to induce immune tolerance to marker gene products and FIX will hold true for the induction of tolerance to FVIII, given FVIII's higher inherent immunogenicity. We are currently addressing is important question in the sheep model.

All of the afore-referenced studies demonstrated that the direct injection of viral vectors into the developing fetus can be an effective way of delivering an exogenous gene and achieving longterm expression in multiple tissues and confirmed the therapeutic potential of an in utero approach to gene therapy. However, for this direct vector injection method of fetal gene delivery to move forward into the clinical arena, vectors that can target specific cell types will likely need to be developed, to eliminate the risk of offtarget modification of undesirable non-target cells, like those of the germline (Park et al., 2004, 2009; Lee et al., 2005). Since such vectors are currently not available, we have been testing the ability of mesenchymal stromal cells (MSC) to serve as vehicles for delivering genes to the developing fetus to safely correct HA and other diseases prior to birth. In the next section of this chapter, we will discuss our rationale for using these cells as therapeutics and summarize results to-date following in utero delivery of MSC.

\section{MESENCHYMAL STROMAL CELLS (MSC) AS HA THERAPEUTICS}

Decades after the pioneering studies of Friedenstein on the marrow microenvironment (Friedenstein et al., 1974; Friedenstein, 1991), results of studies from various labs around the world have revealed that mesenchymal stromal cells (MSC) possess a very broad differentiation potential, both in vitro and in vivo, and exhibit properties that suggest that at least some of the cells contained within this population may be stem cells (Caplan, 1991; Liechty et al., 2000; Mackenzie and Flake, 2001; Fukuda, 2002; Jiang et al., 2002; Airey et al., 2004; Chen et al., 2004b; Kassem, 2004; Porada et al., 2006; Banas et al., 2007; Chamberlain et al., 2007; Colletti et al., 2009a; Porada and Almeida-Porada, 2010). MSC are very rare, only comprising roughly $0.001-0.01 \%$ of cells within the marrow (Galotto et al., 1999). However, they can be passaged extensively in vitro without a loss of differentiative potential, making it possible to readily generate clinically relevant numbers of these cells (Crop et al., 2009). Since MSC were first discovered within the bone marrow, many of the studies performed thus far have utilized MSC isolated from this tissue. However, we and others have now shown that cells with the phenotype and functionality of MSC can also readily be isolated from a variety of different tissues, including umbilical cord blood, kidney, liver, lung, brain, fetal blood, and even adipose tissue collected via liposuction (Zuk et al., 2001, 2002; Almeida-Porada et al., 2002; Morizono et al., 2003; in 't Anker et al., 2003; Lee et al., 2004a; Fan et al., 2005; Gotherstrom et al., 2005). Importantly from the standpoint of in utero therapies, MSC have also been isolated from the amniotic fluid and the chorionic villi, raising the exciting possibility that autologous MSC could be used as cellular therapeutics or gene delivery vehicles for in utero therapy (Poloni et al., 2011; Shaw et al., 2011a,b; Fernandes et al., 2012; Karlsson et al., 2012; Weber et al., 2012).

As discussed earlier, the liver is thought to be the body's main source of FVIII. Studies from our group and others over the past decade have provided compelling evidence that MSC from various sources can give rise, in vitro and in vivo, to cells which appear identical to native hepatocytes, and have shown that transplanting MSC in a range of model systems results in the generation of substantial numbers of hepatocytes, with resultant repair/correction in a variety of inborn genetic defects and injuries (AlmeidaPorada et al., 2001a, 2003a, 2004; Schwartz et al., 2002; Theise and Krause, 2002; Almeida-Porada and Zanjani, 2004; Fang et al., 2004; Sakaida et al., 2004; Lee et al., 2004b; Luk et al., 2005; Sato 
et al., 2005; Zhao et al., 2005; Ishikawa et al., 2006; Oyagi et al., 2006; Popp et al., 2006; Talens-Visconti et al., 2006; Aurich et al., 2007, 2008; Banas et al., 2007, 2008, 2009; Chamberlain et al., 2007; Colletti et al., 2007, 2009b; Higashiyama et al., 2007; Muraca et al., 2007; Sgodda et al., 2007; di Bonzo et al., 2008; Enns and Millan, 2008; Lysy et al., 2008; Zheng and Liang, 2008). We have shown, in the fetal sheep model, that, by performing the transplant at a stage in early gestation when the fetal immune system is still relatively immature, it is possible to achieve significant levels of human cell engraftment. Moreover, because this approach induces donor-specific tolerance, these xenogeneic human cells persist for the whole life of the transplanted animals (AlmeidaPorada et al., 2001a, 2004; Almeida-Porada and Zanjani, 2004). Of direct relevance to HA treatment, we have demonstrated that, after transplantation into fetal sheep, human MSC engraft at levels of up to $12 \%$ within the recipient liver (Almeida-Porada et al., 2000, 2001b, 2003b, 2004; Almeida-Porada and Zanjani, 2004; Chamberlain et al., 2004, 2007; Porada and Almeida-Porada, 2006, 2010), and contribute to both the parenchyma and the perivascular zones, placing them in an ideal location to deliver FVIII into the circulation. Since FVIII levels of only $3-5 \%$ of normal would convert a patient with severe HA to a moderate or mild phenotype, it seems reasonable to conclude that these levels of engraftment should be highly therapeutic. In other recent studies, we have demonstrated that MSC from various tissues throughout the body endogenously produce and secrete biologically active FVIII (Soland et al., 2014). Collectively, these results support the notion that MSC are uniquely and ideally suited for treating HA.

However, upon further analysis, we found that, although MSC engrafted at significant levels within the natural sites of FVIII synthesis, the levels of FVIII production were too low to effectively treat HA. If, however, one were to use gene transfer to engineer MSC to express FVIII, it is likely that the levels of MSC engraftment we routinely achieve following transplantation in utero would be beneficial/therapeutic in HA, especially if newer, expression-optimized FVIII variants were used in the gene therapy vectors (Gangadharan et al., 2006; Doering et al., 2009; Dooriss et al., 2009; Ide et al., 2010). Importantly, MSC can be efficiently transduced with all of the major viral vector systems that are in clinical use, including adenovirus (Bosch et al., 2006; Bosch and Stice, 2007; Roelants et al., 2008), murine retroviruses (Meyerrose et al., 2007; Sales et al., 2007; Piccoli et al., 2008; Roelants et al., 2008; Gnecchi and Melo, 2009), lentiviruses (Zhang et al., 2002, 2004; Meyerrose et al., 2008; Fan et al., 2009; Wang et al., 2009; Xiang et al., 2009), and AAV (Kumar et al., 2004; Stender et al., 2007). Furthermore, in contrast to studies with hematopoietic stem cells (Racine et al., 1995; Fox and Chowdhury, 2004; Muraca and Burlina, 2005), human MSC are stable in culture, do not form tumors in vivo (unlike murine MSC, Tasso et al., 2009), and there is no evidence that transduction can cause human MSC to undergo transformation or progression to clonal dominance. Instead, recent studies have shown that, even following intentional induction of genomic instability, human MSC undergo terminal differentiation rather than transformation (Altanerova et al., 2009), with very rare transformants only arising after very extended in vitro propagation, and being easily identifiable (and removable) based on their altered cell surface marker profile (Pan et al., 2014). As such, MSC appear to represent very safe cellular vehicles for delivering a therapeutic gene.

Looking specifically at using MSC to treat HA, multiple studies have already proven that MSC can be efficiently transduced with murine retroviral and lentiviral vectors with gene cassettes encoding FVIII from a variety of species and produce/release high levels of functional FVIII protein. Importantly, when FVIII was purified from the tissue culture medium of transduced MSC, its specific activity, electrophoretic mobility, and proteolytic activation pattern were all identical to commercially produced FVIII (Doering, 2008). Given the widespread distribution and engraftment of MSC following their transplantation, the ability of MSC to give rise, in vivo, to cells of numerous tissue types, and their ability to efficiently process and secrete significant quantities of biologically active FVIII, it is not surprising that we and others feel that MSC represent ideal vehicles for delivering a FVIII transgene throughout the body, and thereby providing long-term/permanent correction of HA (Van Damme et al., 2003; Doering, 2008; Pipe et al., 2008; Porada et al., 2011).

In addition to their widespread engraftment and their ability to serve as delivery vehicles for the FVIII gene, MSC have rather unique immunological properties that may further increase their utility for treating HA. MSC do not normally express MHC class II or the co-stimulatory molecules CD80 and CD82. As a result, they do not induce allogeneic lymphocytes to proliferate, nor do they serve as very effective targets for cytotoxic T cells or NK cells. Actually, a growing body of evidence exists to support the conclusion that MSC can be transplanted across allogeneic barriers without eliciting a pronounced immune response (Bartholomew et al., 2001; Devine et al., 2001). Thus, it is theoretically possible that HA (and other diseases as well) could be treated using "offthe-shelf" MSC from an unrelated donor, which would greatly facilitate the use of these cells for therapy. It has long been presumed that the immune system is immature/absent in the fetus at the time when in utero transplant is performed. However, recent studies conducted in mice by Mackenzie and Flake have challenged this assumption by showing that the engraftment rate of allogeneic hematopoietic cells can be negatively affected by not only the developing fetal immune system, but also by that of the mother (Peranteau et al., 2007; Nijagal et al., 2011). As such, the success of in utero therapies may also benefit from the hypoimmunogenic state of MSC.

In addition to their unique immune properties, MSC also possess another interesting characteristic that is potentially of great clinical value; the ability to selectively migrate to sites within the body where injury/inflammation exist. Upon arriving at these sites, the MSC then repair the damaged/diseased tissue by: (1) releasing trophic factors that dampen inflammation and stimulate the local tissue's endogenous repair mechanisms; and (2) engrafting within the target tissue and reprogramming to produce tissue-specific cells (Jiang et al., 2005, 2006a,b). This property raises the exciting possibility that, following infusion, FVIIIexpressing MSC might have the ability to selectively traffic to active bleeds/sites of injury, thus directing the therapy to regions of the body that are in greatest need of help. 


\section{PRECLINICAL SUCCESS WITH MSC-BASED TREATMENT FOR HA}

Despite the multiple advantages of early intervention, there are already roughly $1.6 \times 10^{\wedge} 4$ individuals with $\mathrm{HA}$, in the US alone, who obviously could not benefit from the development of a therapy that would be administered prior to birth. Furthermore, over $25 \%$ of the mutations that cause HA arise de novo; as such, it is highly improbable that this group of patients would undergo prenatal screening for HA. We therefore began investigating, in two pediatric HA lambs, whether some of the afore-mentioned properties that make MSC ideally suited for delivering FVIII could still be realized if the MSC engineered to express FVIII are delivered early in childhood. During their first months of life, both HA lambs in this study were given frequent human FVIII treatments in an effort to control multiple hematomas and recurring bleeds in the leg joints, that had given rise to chronic, progressive, debilitating hemarthroses. As a result of these joint bleeds, the two sheep developed extreme postural and gait defects, which made it difficult for them to even stand upright, and precluded them from walking. Given the severe, life-threatening phenotype of the HA sheep, we chose to use cells from the "father" of the two HA lambs (haploidentical), rather than attempting to collect marrow from the two HA lambs to isolate autologous MSC.

Based on our prior in utero studies, we knew that MSC should engraft throughout all of the major organs (Feldmann et al., 1992; Almeida-Porada et al., 2004; Aurich et al., 2006; Russo et al., 2006; Chamberlain et al., 2007; Colletti et al., 2009a) and durably express the vector-encoded genes (Feldmann et al., 1992; Zanjani et al., 1993; Colletti et al., 2009a) following intraperitoneal (IP) injection. The IP route also enabled the MSC to gradually enter the circulation over an extended period of time, as they were absorbed through the peritoneal lymphatics, rather than as a single large bolus, as would occur via IV injection. The IP route also allowed us to avoid the extensive lung-trapping which occurs following IV administration of MSC, promising more efficient delivery of the MSC to the desired target tissues, and eliminating the clinical risk of emboli formation (Traas et al., 2007; Mancuso et al., 2009).

MSC were simultaneously transduced with 2 lentiviral-based vectors; one of which contained a cassette coding for an expression/secretion optimized porcine FVIII (pFVIII) transgene (Yamagami et al., 2006), and the second of which encoded eGFP, to enable us to follow/trace the donor cells in vivo following injection. Two factors drove our choice to use a pFVIII transgene: (1) the cDNA for ovine FVIII had not yet been cloned; and (2) prior studies had shown that, even when expressed in human cells, the pFVIII transgene was produced/secreted at levels that were 10-100 times higher than those seen with hFVIII (Gangadharan et al., 2006; Doering et al., 2007, 2009). As such, we anticipated that even if the transplanted MSC only engrafted/persisted at relatively low levels, they should still be able to exert a clinical benefit. Once the transduced MSC had been sufficiently expanded, transduced MSC were transplanted into the peritoneal cavity of the first animal under ultrasound guidance, without any prior preconditioning of the recipient.

At various time points after transplantation, a highly sensitive chromogenic assay was unable to detect any FVIII activity in the circulation of this animal, but his clinical picture was markedly improved within only days of the transplant. The animal stopped experiencing spontaneous bleeds, and he enjoyed an event-free clinical course, no longer requiring hFVIII infusions. What was most remarkable, however, was that the animal's joints recovered fully. His existing hemarthroses resolved, restoring normal posture and gait, and allowing him to resume a normal activity level. This is the first report describing phenotypic correction of severe HA in a large animal model after transplanting cells modified to express FVIII. It is also the first time that chronic debilitating hemarthroses have been reversed as a result of any type of therapeutic intervention.

Encouraged by this first animal's marked improvement, we performed an identical transplant procedure on a second animal, using a four-fold higher cell dose, in the hopes of achieving detectable FVIII activity in the circulation. Just as had occurred in the first animal, this straightforward procedure resolved existing hemarthroses in this second animal, and he promptly regained normal activity. The transplant also enabled this second animal to achieve factor-independence. These results thus confirm the ability of MSC to serve as highly effective cellular vehicles for delivery a FVIII transgene, and establish their ability to exert a pronounced clinical benefit in this large animal HA model. Nonetheless, the plasma of this second animal, just like that of the first animal, was completely devoid of FVIII activity. As such, the question of the mechanism(s) whereby this procedure produced such clear therapeutic benefit remains unanswered.

Following euthanasia, PCR analysis of tissues collected from these animals confirmed widespread engraftment of significant levels of MSC in all of the tissues we analyzed, including liver, lymph nodes, intestine, lung, kidney, omentum, and thymus. Subsequent analysis of frozen tissue sections by confocal microscopy revealed large numbers of MSC had engrafted within the synovia of the joints that were experiencing hemarthrosis at the time of transplant. Moreover, these MSC were still expressing the vector-encoded FVIII transgene. These analyses thus confirmed the intrinsic ability of transplanted MSC to home to and persist within sites of ongoing injury/inflammation. Furthermore, the continued production/release of FVIII by the engrafted cells, locally within the joint, provided a mechanistic explanation for the pronounced improvement this procedure exerted on the animals' joints. However, the long-term presence of FVIII-expressing MSC within the animals' joints cannot really account for the clear systemic benefits we observed in these animals, the most striking of which was their complete cessation of spontaneous bleeding events.

Confocal microscopy also demonstrated that transplanted MSC had engrafted within the small intestine, in agreement with what we had seen in our prior in utero studies (Feldmann et al., 1992). Since proteins secreted from cells within the intestine should have fairly easy access to the circulation, future studies designed to enhance the levels of intestinal engraftment could likely produce a dramatic improvement in the amount of FVIII that is released into the systemic circulation. Aside from the intestine and injured/diseased joints, MSC engraftment also occurred in the liver, the lungs, and the thymus of the treated animals. Collectively, the results of the PCR and confocal analyses 
strongly support the conclusion that widespread durable engraftment of MSC can be achieved in a large animal model following transplantation in a postnatal setting, without the need for preconditioning/ablation. However, the levels of engraftment seen in these pediatric animals were substantially lower than those obtained in our prior in utero studies. Moreover, despite the marked clinical improvement and the widespread engraftment of the transplanted MSC, both animals mounted a strong immune response to pFVIII, which agrees with prior studies conducted in HA mice (Gangadharan et al., 2006). These inhibitors exhibited cross-reactivity to hFVIII, which was unanticipated, since a good deal of clinical data exist to support the continued efficacy of pFVIII products in human patients that have developed anti-hFVIII inhibitors (VandenDriessche et al., 1999; Brown and Lillicrap, 2002; Bhakta et al., 2006; Son et al., 2006).

Therefore, while this postnatal approach proved that MSC can serve as cellular vehicles to deliver a FVIII transgene and produce a therapeutic benefit, we feel it is safe to conclude that administering this same treatment in utero would have a more pronounced and more durable effect, since higher levels of donor MSC engraftment could be achieved, and because inhibitor formation could be avoided due to the induction of immune tolerance to the FVIII transgene.

\section{ACKNOWLEDGMENTS}

This work was supported by grants R01 HL073737 and R01 HD40228/43038 from the National Institutes of Health, and Clinical Pilot Award 20667 from the Wake Forest University Health Sciences Translational Science Institute.

\section{REFERENCES}

Agaliotis, D. P., Zaiden, R. A., Ozturk, S. (2006). Hemophilia Overview. eMedicine from webMD. Available online at: http://emedicine.medscape.com/article/ 210104-overview (Accessed November 24, 2009).

Airey, J. A., Almeida-Porada, G., Colletti, E. J., Porada, C. D., Chamberlain, J., Movsesian, M., et al. (2004). Human mesenchymal stem cells form purkinje fibers in fetal sheep heart. Circulation 109, 1401-1407. doi: 10.1161/01.CIR.0000124222.16321.26

Almeida-Porada, G., Desai, J., Long, C., Westhusin, M., Pliska, V., Stranzinger, G., et al. (2007). Re-establishment and characterization of an extinct line of sheep with a spontaneous bleeding disorder that closely recapitulates human hemophilia A. Blood 110, 347a.

Almeida-Porada, G., ElShabrawy, D. P. C., and Ascensao, J. L., Zanjani, E. D. (2001b). Clonally derived MSCs Populations are able to differentiate into blood liver and skin cells. Blood 98, 3292a.

Almeida-Porada, G., El Shabrawy, D., Porada, C., and Zanjani, E. D. (2002). Differentiative potential of human metanephric mesenchymal cells. Exp. Hematol. 30, 1454-1462. doi: 10.1016/S0301-472X(02)00967-0

Almeida-Porada, G. P. C. D., Brouard, N., Simmons, P. J., Ascensao, J. L., and Zanjani, E. D. (2000). Generation of hematopoietic and hepatic cells by human bone marrow stromal cells in vivo. Blood. 96, 570a.

Almeida-Porada, G., Porada, C., and Zanjani, E. D. (2001a). Adult stem cell plasticity and methods of detection. Rev. Clin. Exp. Hematol. 5, 26-41. doi: 10.1046/j.1468-0734.2001.00027.x

Almeida-Porada, G., Porada, C., and Zanjani, E. D. (2004). Plasticity of human stem cells in the fetal sheep model of human stem cell transplantation. Int. J. Hematol. 79, 1-6. doi: 10.1007/BF02983526

Almeida-Porada, G., and Zanjani, E. D. (2004). A large animal noninjury model for study of human stem cell plasticity. Blood Cells Mol. Dis. 32, 77-81. doi: 10.1016/j.bcmd.2003.09.018

Almeida-Porada, M. G., Chamberlain, J., Frias, A., Porada, C. D., and Zanjani, E. D. (2003a).Tissue of origin influences in vivo differentiative potential of mesenchymal stem cells. Blood 102, 359a-360a.
Almeida-Porada, M. G., Chamberlain, J., Frias, A., Simmons, P. J., Porada, C. D., and Zanjani, E. D., (2003b). Intra-hepatic injection of clonally derived mesenchymal stem cell $(\mathrm{msc})$ populations results in the successful and efficient generation of liver cells. Blood 102, 340a.

Altanerova, V., Horvathova, E., Matuskova, M., Kucerova, L., and Altaner, C. (2009). Genotoxic damage of human adipose-tissue derived mesenchymal stem cells triggers their terminal differentiation. Neoplasma 56, 542-547. doi: 10.4149/neo_2009_06_542

in 't Anker, P. S., Noort, W. A., Scherjon, S. A., Kleijburg-van der Keur, C., Kruisselbrink, A. B., van Bezooijen, R. L., et al. (2003). Mesenchymal stem cells in human second-trimester bone marrow, liver, lung, and spleen exhibit a similar immunophenotype but a heterogeneous multilineage differentiation potential. Haematologica $88,845-852$.

Arruda, V. R. (2006). Toward gene therapy for hemophilia A with novel adenoviral vectors: successes and limitations in canine models. J. Thromb. Haemost. 4, 1215-1217. doi: 10.1111/j.1538-7836.2006.01964.x

Aurich, H., Sgodda, M., Kaltwasser, P., Vetter, M., Weise, A., Liehr, T., et al. (2008). Hepatocyte differentiation of mesenchymal stem cells from human adipose tissue in vitro promotes hepatic integration in vivo. Gut. 58, 570-581. doi: 10.1136/gut.2008.154880

Aurich, I., Mueller, L. P., Aurich, H., Luetzkendorf, J., Tisljar, K., Dollinger, M., et al. (2006). Functional integration of human mesenchymal stem cell-derived hepatocytes into mouse livers. Gut. 56, 405-415. doi: 10.1136/gut.2005.090050

Aurich, I., Mueller, L. P., Aurich, H., Luetzkendorf, J., Tisljar, K., Dollinger, M. M., et al. (2007). Functional integration of hepatocytes derived from human mesenchymal stem cells into mouse livers. Gut. 56, 405-415. doi: 10.1136/gut.2005.090050

Backfisch, W., Neuenschwander, S., Giger, U., Stranzinger, G., and Pliska, V. (1994). Carrier detection of ovine hemophilia A using an RFLP marker, and mapping of the factor VIII gene on the ovine X-chromosome. J. Hered. 85, 474-478.

Banas, A., Teratani, T., Yamamoto, Y., Tokuhara, M., Takeshita, F., Osaki, M., et al. (2008). IFATS collection: in vivo therapeutic potential of human adipose tissue mesenchymal stem cells after transplantation into mice with liver injury. Stem Cell 26, 2705-2712. doi: 10.1634/stemcells.2008-0034

Banas, A., Teratani, T., Yamamoto, Y., Tokuhara, M., Takeshita, F., Osaki, M., et al. (2009). Rapid hepatic fate specification of adipose-derived stem cells and their therapeutic potential for liver failure. J. Gastroenterol. Hepatol. 24, 70-77. doi: 10.1111/j.1440-1746.2008.05496.x

Banas, A., Teratani, T., Yamamoto, Y., Tokuhara, M., Takeshita, F., Quinn, G., et al. (2007). Adipose tissue-derived mesenchymal stem cells as a source of human hepatocytes. Hepatology 46, 219-228. doi: 10.1002/hep.21704

Bartholomew, A., Patil, S., Mackay, A., Nelson, M., Buyaner, D., Hardy, W., et al. (2001). Baboon mesenchymal stem cells can be genetically modified to secrete human erythropoietin in vivo. Hum. Gene Ther. 12, 1527-1541. doi: $10.1089 / 10430340152480258$

Bhakta, S., Hong, P., and Koc, O. (2006). The surface adhesion molecule CXCR4 stimulates mesenchymal stem cell migration to stromal cell-derived factor-1 in vitro but does not decrease apoptosis under serum deprivation. Cardiovasc. Revasc. Med. 7, 19-24. doi: 10.1016/j.carrev.2005.10.008

Bi, L., Lawler, A. M., Antonarakis, S. E., High, K. A., Gearhart, J. D., Kazazian, H. H., et al. (1995). Targeted disruption of the mouse factor VIII gene produces a model of haemophilia A. Nat. Genet. 10, 119-121. doi: 10.1038/ng0595-119

Billingham, R. E., Brent, L., and Medawar, P. B. (1954). Quantitative studies on tissue transplantation immunity. II. The origin, strength and duration of actively and adoptively acquired immunity. Proc. R. Soc. Lond. B Biol. Sci. 143, 58-80. doi: 10.1098/rspb.1954.0054

di Bonzo, L. V., Ferrero, I., Cravanzola, C., Mareschi, K., Rustichell, D., Novo, E., et al. (2008). Human mesenchymal stem cells as a two-edged sword in hepatic regenerative medicine: engraftment and hepatocyte differentiation versus profibrogenic potential. Gut. 57, 223-231. doi: 10.1136/gut.2006.111617

Bormann, C. L. C., Menges, S., Hanna, C., Foxworth, G., Shin, T., Westhusin, M., et al. (2006). Reestablishment of an extinct strain of sheep from a limited supply of frozen semen. Rep. Fert. Dev. 18, 201. doi: 10.1071/RDv18n2Ab187

Bormann, C., Long, C., Menges, S., Hanna, C., Foxworth, G., Westhusin, M., et al. (2007). Reestablishment of an extinct strain of sheep utilizing assisted reproductive technologies. Rep. Fert. Dev. 21, 153. doi: 10.1071/RDv20n1Ab145

Bosch, P., Fouletier-Dilling, C., Olmsted-Davis, E. A., Davis, A. R., and Stice, S. L. (2006). Efficient adenoviral-mediated gene delivery into porcine mesenchymal stem cells. Mol. Reprod. Dev. 73, 1393-1403. doi: 10.1002/mrd.20593 
Bosch, P., and Stice, S. L. (2007). Adenoviral transduction of mesenchymal stem cells. Methods Mol. Biol. 407, 265-274. doi: 10.1007/978-1-59745-536-7_18

Brown, B. D., and Lillicrap, D. (2002). Dangerous liaisons: the role of "danger" signals in the immune response to gene therapy. Blood 100, 1133-1140. doi: 10.1182/blood-2001-11-0067

Caplan, A. I. (1991). Mesenchymal stem cells. J. Orthop. Res. 9, 641-650. doi: 10.1002/jor.1100090504

Chamberlain, J., Frias, A., Porada, C., Zanjani, E. D., and Almeida-Porada, G. (2004). Clonally derived mesenchymal stem cell (MSC) populations generate liver cells by intra-hepatic injection without the need for a hematopoietic intermediate. Exp. Hematol. 32, 48.

Chamberlain, J., Yamagami, T., Colletti, E., Theise, N. D., Desai, J., Frias, A., et al. (2007). Efficient generation of human hepatocytes by the intrahepatic delivery of clonal human mesenchymal stem cells in fetal sheep. Hepatology 46, 1935-1945. doi: 10.1002/hep.21899

Chen, L. B., Jiang, X. B., and Yang, L. (2004b). Differentiation of rat marrow mesenchymal stem cells into pancreatic islet beta-cells. World J. Gastroenterol. 10, 3016-3020.

Chen, X. G., Zhu, H. Z., Gong, J. L., Li, F., and Xue, J. L. (2004a). Efficient delivery of human clotting factor IX after injection of lentiviral vectors in utero. Acta Pharmacol. Sin. 25, 789-793.

Chitlur, M., Warrier, I., Rajpurkar, M., and Lusher, J. M. (2009). Inhibitors in factor IX deficiency a report of the ISTH-SSC international FIX inhibitor registry (1997-2006). Haemophilia 15, 1027-1031. doi: 10.1111/j.13652516.2009.02039.x

Colletti, E., Airey, J. A., Liu, W., Simmons, P. J., Zanjani, E. D., Porada, C. D., et al. (2009a). Generation of tissue-specific cells by MSC does not require fusion or donor to host mitochondrial/membrane transfer. Stem Cell Res. 2, 125-138. doi: 10.1016/j.scr.2008.08.002

Colletti, E. J., Airey, J. A., Liu, W., Simmons, P. J., Zanjani, E. D., Porada, C. D., et al. (2009b). Generation of tissue-specific cells from MSC does not require fusion or donor-to-host mitochondrial/membrane transfer. Stem Cell Res. 2, 125-138. doi: 10.1016/j.scr.2008.08.002

Colletti, E. J. A. J. A., Zanjani, E. D., Porada, C. D., and Almeida-Porada, G. (2007). Human mesenchymal stem cells differentiate promptly into tissue-specific cell types without cell fusion, mitochondrial or membrane vesicular transfer in fetal sheep. Blood 110, 135a.

Colletti, E., Lindstedt, S., Park, P., Almeida-Porada, G., and Porada, C. (2008). Early fetal gene delivery utilizes both central and peripheral mechanisms of tolerance induction. Exp. Hematol. 36, 816-822. doi: 10.1016/j.exphem.2008.02.007

Crop, M., Baan, C., Weimar, W., and Hoogduijn, M. (2009). Potential of mesenchymal stem cells as immune therapy in solid-organ transplantation. Transpl. Int. 22, 365-376. doi: 10.1111/j.1432-2277.2008.00786.x

David, A., Cook, T., Waddington, S., Peebles, D., Nivsarkar, M., Knapton, H., et al. (2003). Ultrasound-guided percutaneous delivery of adenoviral vectors encoding the beta-galactosidase and human factor IX genes to early gestation fetal sheep in utero. Hum. Gene Ther. 14, 353-364. doi: 10.1089/104303403321208952

David, A. L., McIntosh, J., Peebles, D. M., Cook, T., Waddington, S., Weisz, B., et al. (2011). Recombinant adeno-associated virus-mediated in utero gene transfer gives therapeutic transgene expression in the sheep. Hum. Gene Ther. 22, 419-426. doi: 10.1089/hum.2010.007

Devine, S. M., Bartholomew, A. M., Mahmud, N., Nelson, M., Patil, S., Hardy, W., et al. (2001). Mesenchymal stem cells are capable of homing to the bone marrow of non-human primates following systemic infusion. Exp. Hematol. 29, 244-255. doi: 10.1016/S0301-472X(00)00635-4

Doering, C. B. (2008). Retroviral modification of mesenchymal stem cells for gene therapy of hemophilia. Methods Mol. Biol. 433, 203-212. doi: 10.1007/978-159745-237-3_12

Doering, C. B., Denning, G., Dooriss, K., Gangadharan, B., Johnston, J. M., Kerstann, K. W., et al. (2009). Directed engineering of a high-expression chimeric transgene as a strategy for gene therapy of hemophilia A. Mol. Ther. 17, 1145-1154. doi: 10.1038/mt.2009.35

Doering, C. B., Gangadharan, B., Dukart, H. Z., and Spencer, H. T. (2007). Hematopoietic stem cells encoding porcine factor VIII induce pro-coagulant activity in hemophilia A mice with pre-existing factor VIII immunity. Mol. Ther. 15, 1093-1099. doi: 10.1038/sj.mt.6300146

Dooriss, K. L., Denning, G., Gangadharan, B., Javazon, E. H., Spencer, H. T., and Doering, C. (2009). Comparison of factor viii transgenes bioengineered for improved expression in gene therapy of hemophilia A. Hum. Gene Ther. 20, 465-478. doi: 10.1089/hum.2008.150

Ehrenforth, S., Kreuz, W., Scharrer, I., Linde, R., Funk, M., Gungor, T., et al. (1992). Incidence of development of factor VIII and factor IX inhibitors in haemophiliacs. Lancet 339, 594-598. doi: 10.1016/0140-6736(92)90874-3

Enns, G. M., and Millan, M. T. (2008). Cell-based therapies for metabolic liver disease. Mol. Genet. Metab. 95, 3-10. doi: 10.1016/j.ymgme.2008.06.001

Fahs, S. A., Hille, M. T., Shi, Q., Weiler, H., and Montgomery, R. R. (2014). A conditional knockout mouse model reveals endothelial cells as the principal and possibly exclusive source of plasma factor VIII. Blood 123, 3706-3713. doi: 10.1182/blood-2014-02-555151

Fan, C. G., Tang, F. W., Zhang, Q. J., Lu, S. H., Liu, H. Y., Zhao, Z. M., et al. (2005). Characterization and neural differentiation of fetal lung mesenchymal stem cells. Cell Transplant. 14, 311-321. doi: 10.3727/000000005783983070

Fan, L., Lin, C., Zhuo, S., Chen, L., Liu, N., Luo, Y., et al. (2009). Transplantation with survivin-engineered mesenchymal stem cells results in better prognosis in a rat model of myocardial infarction. Eur. J. Heart Fail. 11, 1023-1030. doi: 10.1093/eurjhf/hfp135

Fang, B., Shi, M., Liao, L., Yang, S., Liu, Y., and Zhao, R. C. (2004). Systemic infusion of FLK1(+) mesenchymal stem cells ameliorate carbon tetrachloride-induced liver fibrosis in mice. Transplantation 78, 83-88. doi: 10.1097/01.TP.0000128326.95294.14

Feldmann, G., Scoazec, J. Y., Racine, L., and Bernuau, D. (1992). Functional hepatocellular heterogeneity for the production of plasma proteins. Enzyme 46, 139-154.

Fernandes, R. A., Wenceslau, C. V., Reginato, A. L., Kerkis, I., and Miglino, M. A. (2012). Derivation and characterization of progenitor stem cells from canine allantois and amniotic fluids at the third trimester of gestation. Placenta. 33, 640-644. doi: 10.1016/j.placenta.2012.03.009

Flake, A. W., Roncarolo, M. G., Puck, J. M., Almeida-Porada, G., Evans, M. I., Johnson, M. P., et al. (1996). Treatment of X-linked severe combined immunodeficiency by in utero transplantation of paternal bone marrow. N. Engl. J. Med. 335, 1806-1810. doi: 10.1056/NEJM199612123352404

Flake, A. W., and Zanjani, E. D. (1999). In utero hematopoietic stem cell transplantation: ontogenic opportunities and biologic barriers. Blood 94, 2179-2191.

Fox, I. J., and Chowdhury, J. R. (2004). Hepatocyte transplantation. Am. J. Transplant. 4(Suppl. 6), 7-13. doi: 10.1111/j.1600-6135.2004.0340.x

Friedenstein, A. J. (1991). Osteogenic stem cells in the bone marrow. Bone Miner. 7, 243-272.

Friedenstein, A. J., Chailakhyan, R. K., Latsinik, N. V., Panasyuk, A. F., and KeilissBorok, I. V. (1974). Stromal cells responsible for transferring the microenvironment of the hemopoietic tissues. Cloning in vitro and retransplantation in vivo. Transplantation 17, 331-340. doi: 10.1097/00007890-197404000-00001

Fukuda, K. (2002). Reprogramming of bone marrow mesenchymal stem cells into cardiomyocytes. C. R. Biol. 325, 1027-1038. doi: 10.1016/S16310691(02)01524-X

Gallo-Penn, A. M., Shirley, P. S., Andrews, J. L., Kayda, D. B., Pinkstaff, A. M., Kaloss, M., et al. (1999). In vivo evaluation of an adenoviral vector encoding canine factor VIII: high-level, sustained expression in hemophiliac mice. Hum. Gene Ther. 10, 1791-1802. doi: 10.1089/10430349950017473

Gallo-Penn, A. M., Shirley, P. S., Andrews, J. L., Tinlin, S., Webster, S., Cameron, C., et al. (2001). Systemic delivery of an adenoviral vector encoding canine factor VIII results in short-term phenotypic correction, inhibitor development, and biphasic liver toxicity in hemophilia A dogs. Blood 97, 107-113. doi: 10.1182/blood.V97.1.107

Galotto, M., Berisso, G., Delfino, L., Podesta, M., Ottaggio, L., Dallorso, S., et al. (1999). Stromal damage as consequence of high-dose chemo/radiotherapy in bone marrow transplant recipients. Exp. Hematol. 27, 1460-1466. doi: 10.1016/S0301-472X(99)00076-4

Gangadharan, B., Parker, E. T., Ide, L. M., Spencer, H. T., and Doering, C. B. (2006). High-level expression of porcine factor VIII from genetically modified bone marrow-derived stem cells. Blood 107, 3859-3864. doi: 10.1182/blood-2005-124961

Garcia-Martin, C., Chuah, M. K., Van Damme, A., Robinson, K. E., Vanzieleghem, B., Saint-Remy, J. M., et al. (2002). Therapeutic levels of human factor VIII in mice implanted with encapsulated cells: potential for gene therapy of haemophilia A. J. Gene Med. 4, 215-223. doi: 10.1002/jgm.248

Gnecchi, M., and Melo, L. G. (2009). Bone marrow-derived mesenchymal stem cells: isolation, expansion, characterization, viral transduction, and production 
of conditioned medium. Methods Mol. Biol. 482:281-294. doi: 10.1007/978-159745-060-7_18

Gotherstrom, C., West, A., Liden, J., Uzunel, M., Lahesmaa, R., and Le Blanc, K. (2005). Difference in gene expression between human fetal liver and adult bone marrow mesenchymal stem cells. Haematologica 90, 1017-1026.

Higashiyama, R., Inagaki, Y., Hong, Y. Y., Kushida, M., Nakao, S., Niioka, M., et al. (2007). Bone marrow-derived cells express matrix metalloproteinases and contribute to regression of liver fibrosis in mice. Hepatology 45, 213-222. doi: 10.1002/hep.21477

High, K. A. (2003). Gene transfer as an approach to treating hemophilia. Semin. Thromb. Hemost. 29, 107-120. doi: 10.1055/s-2003-37945

High, K. A. (2011). Gene therapy for haemophilia: a long and winding road. J. Thromb. Haemost. 9, 2-11. doi: 10.1111/j.1538-7836.2011.04369.x

Hough, C., Kamisue, S., Cameron, C., Notley, C., Tinlin, S., Giles, A., et al. (2002). Aberrant splicing and premature termination of transcription of the FVIII gene as a cause of severe canine hemophilia A: similarities with the intron 22 inversion mutation in human hemophilia. Thromb. Haemost. 87, 659-665.

Ide, L. M., Gangadharan, B., Chiang, K. Y., Doering, C. B., and Spencer, H. T. (2007). Hematopoietic stem-cell gene therapy of hemophilia A incorporating a porcine factor VIII transgene and nonmyeloablative conditioning regimens. Blood 110, 2855-2863. doi: 10.1182/blood-2007-04-082602

Ide, L. M., Iwakoshi, N. N., Gangadharan, B., Jobe, S., Moot, R., McCarty, D., et al. (2010). Functional aspects of factor VIII expression after transplantation of genetically-modified hematopoietic stem cells for hemophilia A. J. Gene Med. 12, 333-344. doi: 10.1002/jgm.1442

Ishikawa, T., Terai, S., Urata, Y., Marumoto, Y., Aoyama, K., Sakaida, I., et al. (2006). Fibroblast growth factor 2 facilitates the differentiation of transplanted bone marrow cells into hepatocytes. Cell Tissue Res. 323, 221-231. doi: 10.1007/s00441-005-0077-0

Jeanblanc, C., Goodrich, A. D., Colletti, E., Mokhtari, S., Porada, C. D., Zanjani, E. D., et al. (2014). Temporal definition of haematopoietic stem cell niches in a large animal model of in utero stem cell transplantation. Br. J. Haematol. 166, 268-278. doi: 10.1111/bjh.12870

Jiang, W. H., Ma, A. Q., Zhang, Y. M., Han, K., Liu, Y., Zhang, Z. T., et al. (2005). Migration of intravenously grafted mesenchymal stem cells to injured heart in rats. Sheng Li Xue. Bao. 57, 566-572.

Jiang, W., Ma, A., Wang, T., Han, K., Liu, Y., Zhang, Y., et al. (2006a). Homing and differentiation of mesenchymal stem cells delivered intravenously to ischemic myocardium in vivo: a time-series study. Pflugers Arch. 453, 43-52. doi: 10.1007/s00424-006-0117-y

Jiang, W., Ma, A., Wang, T., Han, K., Liu, Y., Zhang, Y., et al. (2006b). Intravenous transplantation of mesenchymal stem cells improves cardiac performance after acute myocardial ischemia in female rats. Transpl. Int. 19, 570-580. doi: 10.1111/j.1432-2277.2006.00307.x

Jiang, Y., Jahagirdar, B. N., Reinhardt, R. L., Schwartz, R. E., Keene, C. D., OrtizGonzalez, X. R., et al. (2002). Pluripotency of mesenchymal stem cells derived from adult marrow. Nature 418, 41-49. doi: 10.1038/nature00870

Jimenez, D. F., Lee, C. I., O’Shea, C. E., Kohn, D. B., and Tarantal, A. F. (2005). HIV-1-derived lentiviral vectors and fetal route of administration on transgene biodistribution and expression in rhesus monkeys. Gene Ther. 12, 821-830. doi: 10.1038/sj.gt.3302464

Karlsson, H., Erkers, T., Nava, S., Ruhm, S., Westgren, M., and Ringden, O. (2012). Stromal cells from term fetal membrane are highly suppressive in allogeneic settings in vitro. Clin. Exp. Immunol. 167, 543-555. doi: 10.1111/j.13652249.2011.04540.x

Kassem, M. (2004). Mesenchymal stem cells: biological characteristics and potential clinical applications. Cloning Stem Cells 6, 369-374. doi: 10.1089/clo.2004.6.369

Kaveri, S. V., Dasgupta, S., Andre, S., Navarrete, A. M., Repesse, Y., Wootla, B., et al. (2007). Factor VIII inhibitors: role of von Willebrand factor on the uptake of factor VIII by dendritic cells. Haemophilia 13(Suppl. 5), 61-64. doi: $10.1111 / \mathrm{j} .1365-2516.2007 .01575 . x$

Kay, M. A., and High, K. (1999). Gene therapy for the hemophilias. Proc. Natl. Acad. Sci. U.S.A. 96, 9973-99735. doi: 10.1073/pnas.96.18.9973

Klein, I., Andrikovics, H., Bors, A., Nemes, L., Tordai, A., and Varadi, A. (2001). A haemophilia A and B molecular genetic diagnostic programme in Hungary: a highly informative and cost-effective strategy. Haemophilia 7, 306-312. doi: 10.1046/j.1365-2516.2001.00497.x

Kumar, S., Mahendra, G., Nagy, T. R., and Ponnazhagan, S. (2004). Osteogenic differentiation of recombinant adeno-associated virus 2-transduced murine mesenchymal stem cells and development of an immunocompetent mouse model for ex vivo osteoporosis gene therapy. Hum. Gene Ther. 15, 1197-1206. doi: 10.1089/hum.2004.15.1197

Lee, C. C., Jimenez, D. F., Kohn, D. B., and Tarantal, A. F. (2005). Fetal gene transfer using lentiviral vectors and the potential for germ cell transduction in rhesus monkeys (Macaca mulatta). Hum. Gene Ther. 16, 417-425. doi: 10.1089/hum.2005.16.417

Lee, K. D., Kuo, T. K., Whang-Peng, J., Chung, Y. F., Lin, C. T., Chou, S. H., et al. (2004b). In vitro hepatic differentiation of human mesenchymal stem cells. Hepatology 40, 1275-1284.

Lee, O. K., Kuo, T. K., Chen, W. M., Lee, K. D., Hsieh, S. L., and Chen, T. H. (2004a). Isolation of multipotent mesenchymal stem cells from umbilical cord blood. Blood 103, 1669-1675. doi: 10.1182/blood-2003-05-1670

Liechty, K. W., MacKenzie, T. C., Shaaban, A. F., Radu, A., Moseley, A. M., Deans, R., et al. (2000). Human mesenchymal stem cells engraft and demonstrate sitespecific differentiation after in utero transplantation in sheep. Nat. Med. 6, 1282-1286. doi: 10.1038/81395

Lipshutz, G. S., Flebbe-Rehwaldt, L., and Gaensler, K. M. (2000). Reexpression following readministration of an adenoviral vector in adult mice after initial in utero adenoviral administration. Mol. Ther. 2, 374-380. doi: 10.1006/mthe. 2000.0136

Lipshutz, G. S., Sarkar, R., Flebbe-Rehwaldt, L., Kazazian, H., and Gaensler, K. M. (1999). Short-term correction of factor VIII deficiency in a murine model of hemophilia A after delivery of adenovirus murine factor VIII in utero. Proc. Natl. Acad. Sci. U.S.A. 96, 13324-13329. doi: 10.1073/pnas.96.23.13324

Lozier, J. N., Dutra, A., Pak, E., Zhou, N., Zheng, Z., Nichols, T. C., et al. (2002). The chapel hill hemophilia A dog colony exhibits a factor VIII gene inversion. Proc. Natl. Acad. Sci. U.S.A. 99, 12991-12996. doi: 10.1073/pnas.192219599

Luk, J. M., Wang, P. P., Lee, C. K., Wang, J. H., and Fan, S. T. (2005). Hepatic potential of bone marrow stromal cells: development of in vitro co-culture and intra-portal transplantation models. J. Immunol. Methods 305, 39-47. doi: 10.1016/j.jim.2005.07.006

Lysy, P. A., Campard, D., Smets, F., Malaise, J., Mourad, M., Najimi, M., et al. (2008). Persistence of a chimerical phenotype after hepatocyte differentiation of human bone marrow mesenchymal stem cells. Cell Prolif. 41, 36-58. doi: 10.1111/j.1365-2184.2007.00507.x

Mackenzie, T. C., and Flake, A. W. (2001). Multilineage differentiation of human MSC after in utero transplantation. Cytotherapy 3, 403-405. doi: $10.1080 / 146532401753277571$

Maddox, J. F., Mackay, C. R., and Brandon, M. R. (1987a). Ontogeny of ovine lymphocytes. I. An immunohistological study on the development of T lymphocytes in the sheep embryo and fetal thymus. Immunology 62, 97-105.

Maddox, J. F., Mackay, C. R., and Brandon, M. R. (1987b). Ontogeny of ovine lymphocytes. III. An immunohistological study on the development of $\mathrm{T}$ lymphocytes in sheep fetal lymph nodes. Immunology 62, 113-118.

Maddox, J. F., Mackay, C. R., and Brandon, M. R. (1987c). Ontogeny of ovine lymphocytes. II. An immunohistological study on the development of T lymphocytes in the sheep fetal spleen. Immunology 62, 107-112.

Mancuso, M. E., Graca, L., Auerswald, G., and Santagostino, E. (2009). Haemophilia care in children-benefits of early prophylaxis for inhibitor prevention. Haemophilia 15(Suppl. 1), 8-14. doi: 10.1111/j.1365-2516.2008. 01947.x

Mannucci, P. M., and Tuddenham, E. G. (2001). The hemophilias-from royal genes to gene therapy. N. Engl. J. Med. 344, 1773-1779. doi: 10.1056/NEJM200106073442307

Mattar, C. N., Nathwani, A. C., Waddington, S. N., Dighe, N., Kaeppel, C., Nowrouzi, A., et al. (2011). Stable human FIX expression after 0.9G intrauterine gene transfer of self-complementary adeno-associated viral vector 5 and 8 in macaques. Mol. Ther. 19, 1950-1960. doi: 10.1038/mt.2011.107

Matzinger, P. (2002). An innate sense of danger. Ann. N.Y. Acad. Sci. 961, 341-342. doi: $10.1111 / j .1749-6632.2002 . t b 03118 . x$

McCarroll, D. R., Waters, D. C., Steidley, K. R., Clift, R., and McDonald, T. P. (1988). Canine platelet von willebrand factor: quantification and multimeric analysis. Exp. Hematol. 16, 929-937.

Merianos, D., Heaton, T., and Flake, A. W. (2008). In utero hematopoietic stem cell transplantation: progress toward clinical application. Biol. Blood Marrow Transplant. 14, 729-740. doi: 10.1016/j.bbmt.2008.02.012

Meyerrose, T. E., De Ugarte, D. A., Hofling, A. A., Herrbrich, P. E., Cordonnier, T. D., Shultz, L. D., et al. (2007). In vivo distribution of human adipose-derived 
mesenchymal stem cells in novel xenotransplantation models. Stem Cells 25, 220-227. doi: 10.1634/stemcells.2006-0243

Meyerrose, T. E., Roberts, M., Ohlemiller, K. K., Vogler, C. A., Wirthlin, L., Nolta, J. A., et al. (2008). Lentiviral-transduced human mesenchymal stem cells persistently express therapeutic levels of enzyme in a xenotransplantation model of human disease. Stem Cells 26, 1713-1722. doi: 10.1634/stemcells. 2008-0008

Moayeri, M., Hawley, T. S., and Hawley, R. G. (2005). Correction of murine hemophilia A by hematopoietic stem cell gene therapy. Mol. Ther. 12, 1034-1042. doi: 10.1016/j.ymthe.2005.09.007

Moayeri, M., Ramezani, A., Morgan, R. A., Hawley, T. S., and Hawley, R. G. (2004). Sustained phenotypic correction of hemophilia A mice following oncoretroviral-mediated expression of a bioengineered human factor VIII gene in long-term hematopoietic repopulating cells. Mol. Ther. 10, 892-902. doi: 10.1016/j.ymthe.2004.08.006

Montgomery, R. R., and Shi, Q. (2012). Platelet and endothelial expression of clotting factors for the treatment of hemophilia. Thromb. Res. 129(Suppl. 2), S46-S48. doi: 10.1016/j.thromres.2012.02.031

Morizono, K., De Ugarte, D. A., Zhu, M., Zuk, P., Elbarbary, A., Ashjian, P., et al. (2003). Multilineage cells from adipose tissue as gene delivery vehicles. Hum. Gene Ther. 14, 59-66. doi: 10.1089/10430340360464714

Muraca, M., and Burlina, A. B. (2005). Liver and liver cell transplantation for glycogen storage disease type IA. Acta Gastroenterol. Belg. 68, 469-472.

Muraca, M., Ferraresso, C., Vilei, M. T., Granato, A., Quarta, M., Cozzi, E., et al. (2007). Liver repopulation with bone marrow derived cells improves the metabolic disorder in the gunn rat. Gut 56, 1725-1735. doi: 10.1136/gut.2007.127969

Nathwani, A. C., Tuddenham, E. G., Rangarajan, S., Rosales, C., McIntosh, J., Linch, D. C., et al. (2011). Adenovirus-associated virus vector-mediated gene transfer in hemophilia B. N. Engl. J. Med. 365, 2357-2365. doi: 10.1056/NEJMoa 1108046

Neuenschwander, S., Kissling-Albrecht, L., Heiniger, J., Backfisch, W., Stranzinger, G., and Pliska, V. (1992). Inherited defect of blood clotting factor VIII (haemophilia A) in sheep. Thromb. Haemost. 68, 618-620.

Neuenschwander, S., and Pliska, V. (1994). Factor VIII in blood plasma of haemophilic sheep: analysis of clotting time-plasma dilution curves. Haemostasis 24, 27-35.

Nichols, T. C., Dillow, A. M., Franck, H. W., Merricks, E. P., Raymer, R. A., Bellinger, D. A., et al. (2009). Protein replacement therapy and gene transfer in canine models of hemophilia A, hemophilia B, von willebrand disease, and factor VII deficiency. ILAR J. 50, 144-167. doi: 10.1093/ilar.50.2.144

Nijagal, A., Wegorzewska, M., Jarvis, E., Le, T., Tang, Q., and MacKenzie, T. C. (2011). Maternal T cells limit engraftment after in utero hematopoietic cell transplantation in mice. J. Clin. Invest. 121, 582-592. doi: 10.1172/JCI44907

Osburn, B. I. (1981). The ontogeny of the ruminant immune system and its significance in the understanding of maternal-fetal-neonatal relationships. Adv. Exp. Med. Biol. 137, 91-103.

Oyagi, S., Hirose, M., Kojima, M., Okuyama, M., Kawase, M., Nakamura, T., et al. (2006). Therapeutic effect of transplanting HGF-treated bone marrow mesenchymal cells into CCl4-injured rats. J. Hepatol. 44, 742-748. doi: 10.1016/j.jhep.2005.10.026

Pan, Q., Fouraschen, S. M., de Ruiter, P. E., Dinjens, W. N., Kwekkeboom, J., Tilanus, H. W., et al. (2014). Detection of spontaneous tumorigenic transformation during culture expansion of human mesenchymal stromal cells. Exp. Biol. Med. 239, 105-115. doi: 10.1177/1535370213506802

Park, P. J., Almeida-Porada, G., Glimp, H. A., Zanjani, E. D., and Porada, C. D. (2003b). Germline cells may be at risk following direct injection gene therapy in utero. Blood. 102, 874a.

Park, P. J., Colletti, E., Ozturk, F., Wood, J. A., Tellez, J., Almeida-Porada, G., et al. (2009). Factors determining the risk of inadvertent retroviral transduction of male germ cells after in utero gene transfer in sheep. Hum. Gene Ther. 20, 201-215. doi: 10.1089/hum.2007.120

Park, P. J., Tellez, J., Almeida-Porada, G., Zanjani, E. D., and Porada, C. D. (2004). Male germline cells appear to be at risk following direct injection gene transfer in utero. Mol. Ther. 9(Suppl. 1), S403. doi: 10.1016/j.ymthe.2005.05.011

Park, P., Zanjani, E. D., and Porada, C. D. (2003a). Risks to the germline following in utero gene transfer. Mol. Ther. 7, S137.

Parker, M. T., Turrentine, M. A., and Johnson, G. S. (1991). von Willebrand factor in lysates of washed canine platelets. Am. J. Vet. Res. 52, 119-125.
Peranteau, W. H., Endo, M., Adibe, O. O., and Flake, A. W. (2007). Evidence for an immune barrier after in utero hematopoietic-cell transplantation. Blood 109, 1331-1333. doi: 10.1182/blood-2006-04-018606

Peyvandi, F. (2005). Carrier detection and prenatal diagnosis of hemophilia in developing countries. Semin. Thromb. Hemost. 31, 544-554. doi: 10.1055/s2005-922226

Piccoli, C., Scrima, R., Ripoli, M., Di Ianni, M., Del Papa, B., D’Aprile, A., et al. (2008). Transformation by retroviral vectors of bone marrow-derived mesenchymal cells induces mitochondria-dependent cAMP-sensitive reactive oxygen species production. Stem Cells 26, 2843-2854. doi: 10.1634/stemcells.2007-0885

Pipe, S. W., High, K. A., Ohashi, K., Ural, A. U., and Lillicrap, D. (2008). Progress in the molecular biology of inherited bleeding disorders. Haemophilia 14(Suppl. 3), 130-137. doi: 10.1111/j.1365-2516.2008.01718.x

Poloni, A., Maurizi, G., Babini, L., Serrani, F., Berardinelli, E., Mancini, S., et al. (2011). Human mesenchymal stem cells from chorionic villi and amniotic fluid are not susceptible to transformation after extensive in vitro expansion. Cell Transplant. 20, 643-654. doi: 10.3727/096368910X536518

Ponder, K. P. (2006). Gene therapy for hemophilia. Curr. Opin. Hematol. 13, 301-307. doi: 10.1097/01.moh.0000239700.94555.b1

Ponder, K. P. (2011). Hemophilia gene therapy: a Holy Grail found. Mol. Ther. 19, 427-428. doi: 10.1038/mt.2011.13

Popp, F. C., Piso, P., Schlitt, H. J., and Dahlke, M. H. (2006). Therapeutic potential of bone marrow stem cells for liver diseases. Curr. Stem Cell Res. Ther. 1, 411-418. doi: 10.2174/157488806778226759

Porada, C. D., and Almeida-Porada, G. (2010). Mesenchymal stem cells as therapeutics and vehicles for gene and drug delivery. Adv. Drug Deliv. Rev. 2, 1156-1166. doi: 10.1016/j.addr.2010.08.010

Porada, C. D., Almeida-Porada, M. G., Park, P., and Zanjani, E. D. (2001b). In utero transduction of lung and liver: gestational age determines gene transfer efficiency. Blood 98(Pt 1), 215a.

Porada, C. D., Almeida-Porada, M. G., Torabi, A., and Zanjani, E. D. (2001a). In utero transduction of hematopoietic cells is enhanced at early gestational ages. Blood 98(Pt 1), 214a.

Porada, C. D., Harrison-Findik, D. D., Sanada, C., Valiente, V., Thain, D., Simmons, P. J., et al. (2008). Development and characterization of a novel CD34 monoclonal antibody that identifies sheep hematopoietic stem/progenitor cells. Exp. Hematol. 36, 1739-1749. doi: 10.1016/j.exphem.2008.09.003

Porada, C. D., Park, P., Almeida-Porada, G., and Zanjani, E. D. (2004a). The sheep model of in utero gene therapy. Fetal Diagn. Ther. 19, 23-30. doi: $10.1159 / 000074255$

Porada, C. D., Park, P. J., Almeida-Porada, G., Liu, W., Ozturk, F., Glimp, H. A., et al. (2005a). Gestational age of recipient determines pattern and level of transgene expression following in utero retroviral gene transfer. Mol. Ther. 11, 284-293. doi: 10.1016/j.ymthe.2004.09.009

Porada, C. D., Park, P. J., Tellez, J., Ozturk, F., Glimp, H. A., Almeida-Porada, G., et al. (2005b). Male germ-line cells are at risk following direct-injection retroviral-mediated gene transfer in utero. Mol. Ther. 12, 754-762. doi: 10.1016/j.ymthe.2005.05.011

Porada, C. D., Park, P., Torabi, A., Almeida-Porada, G., and Zanjani, E. D. (2002a). "Gestational age determines gene transfer efficiency to hematopoietic cells, lung, and liver following in utero retroviral-mediated gene transfer," in Molecular Therapy, ASGT Annual Meeting (Boston, MA) 5, S402.

Porada, C. D., Sanada, C., Kuo, C. J., Colletti, E., Mandeville, W., Hasenau, J., et al. (2011). Phenotypic correction of hemophilia A in sheep by postnatal intraperitoneal transplantation of FVIII-expressing MSC. Exp. Hematol. 39, 1124-1135. doi: 10.1016/j.exphem.2011.09.001

Porada, C. D., Sanada, C., Long, C. R., Wood, J. A., Desai, J., Frederick, N., et al. (2010). Clinical and molecular characterization of a re-established line of sheep exhibiting hemophilia A. J. Thromb. Haemost. 8, 276-285. doi: 10.1111/j.15387836.2009.03697.x

Porada, C. D., Tran, N. D., Almeida-Porada, G., Glimp, H. A., Pixley, J. S., Zhao, Y., et al. (2002b). Transduction of long-term-engrafting human hematopoietic stem cells by retroviral vectors. Hum. Gene Ther. 13, 867-879. doi: $10.1089 / 10430340252899037$

Porada, C. D., Tran, N., Eglitis, M., Moen, R. C., Troutman, L., Flake, A. W., et al. (1998). In utero gene therapy: transfer and long-term expression of the bacterial neo(r) gene in sheep after direct injection of retroviral vectors into preimmune fetuses. Hum. Gene Ther. 9, 1571-1585. doi: 10.1089/hum.1998.9.11-1571 
Porada, C. D. Z. E., and Almeida-Porada, G. (2006). Adult mesenchymal stem cells: a pluripotent population with multiple applications. Curr. Stem Cell Res. Ther. 1, 231-238. doi: 10.2174/157488806778226821

Porada, C., Zanjani, E., and Almeida-Porada, G. (2006). Adult mesenchymal stem cells: a pluripotent population with multiple applications. Curr. Stem Cell Res. Ther. 1, 231-238. doi: 10.2174/157488806778226821

Porada, G. A., Porada, C., and Zanjani, E. D. (2004b). The fetal sheep: a unique model system for assessing the full differentiative potential of human stem cells. Yonsei Med. J. 45(Suppl.), 7-14. doi: 10.3349/ymj.2004.45

Racine, L., Scoazec, J. Y., Moreau, A., Chassagne, P., Bernuau, D., and Feldmann, G. (1995). Distribution of albumin, alpha 1-inhibitor 3 and their respective mRNAs in periportal and perivenous rat hepatocytes isolated by the digitonincollagenase technique. Biochem. J. 305(Pt 1), 263-268.

Reddy, P. S., Sakhuja, K., Ganesh, S., Yang, L., Kayda, D., Brann, T., et al. (2002). Sustained human factor VIII expression in hemophilia A mice following systemic delivery of a gutless adenoviral vector. Mol. Ther. 5, 63-73. doi: 10.1006/mthe.2001.0510

Roelants, V., Labar, D., de Meester, C., Havaux, X., Tabilio, A., Gambhir, S. S., et al. (2008). Comparison between adenoviral and retroviral vectors for the transduction of the thymidine kinase PET reporter gene in rat mesenchymal stem cells. J. Nucl. Med. 49, 1836-1844. doi: 10.2967/jnumed.108.052175

Roybal, J. L., Santore, M. T., and Flake, A. W. (2010). Stem cell and genetic therapies for the fetus. Semin. Fetal Neonatal Med. 15, 46-51. doi: 10.1016/j.siny.2009.05.005

Russo, F. P., Alison, M. R., Bigger, B. W., Amofah, E., Florou, A., Amin, F., et al. (2006). The bone marrow functionally contributes to liver fibrosis. Gastroenterology 130, 1807-1821. doi: 10.1053/j.gastro.2006.01.036

Sakaida, I., Terai, S., Yamamoto, N., Aoyama, K., Ishikawa, T., Nishina, H., et al. (2004). Transplantation of bone marrow cells reduces CCl4-induced liver fibrosis in mice. Hepatology 40, 1304-1311. doi: 10.1002/hep.20452

Sales, V. L., Mettler, B. A., Lopez-Ilasaca, M., Johnson, J. A. Jr., and Mayer, J. E. Jr. (2007). Endothelial progenitor and mesenchymal stem cell-derived cells persist in tissue-engineered patch in vivo: application of green and red fluorescent protein-expressing retroviral vector. Tissue Eng. 13, 525-535. doi: 10.1089/ten.2006.0128

Sanada, C., Wood, J. A., Liu, W., Lozier, J. N., Almeida-Porada, G., and Porada, C. D. (2008). A frame shift-induced stop codon causes hemophilia a in sheep. Blood 112 .

Sarkar, R., Tetreault, R., Gao, G., Wang, L., Bell, P., Chandler, R., et al. (2004). Total correction of hemophilia A mice with canine FVIII using an AAV 8 serotype. Blood 103, 1253-1260. doi: 10.1182/blood-2003-08-2954

Sasanakul, W., Chuansumrit, A., Ajjimakorn, S., Krasaesub, S., Sirachainan, N., Chotsupakarn, S., et al. (2003). Cost-effectiveness in establishing hemophilia carrier detection and prenatal diagnosis services in a developing country with limited health resources. Southeast Asian J. Trop. Med. Public Health. 34, 891-898.

Sato, Y., Araki, H., Kato, J., Nakamura, K., Kawano, Y., Kobune, M., et al. (2005). Human mesenchymal stem cells xenografted directly to rat liver are differentiated into human hepatocytes without fusion. Blood 106, 756-763. doi: 10.1182/blood-2005-02-0572

Sawyer, M., Moe, J., and Osburn, B. I. (1978). Ontogeny of immunity and leukocytes in the ovine fetus and elevation of immunoglobulins related to congenital infection. Am. J. Vet. Res. 39, 643-648.

Scallan, C. D., Lillicrap, D., Jiang, H., Qian, X., Patarroyo-White, S. L., Parker, A. E., et al. (2003). Sustained phenotypic correction of canine hemophilia A using an adeno-associated viral vector. Blood 102, 2031-2037. doi: 10.1182/blood-200301-0292

Schneider, H., Adebakin, S., Themis, M., Cook, T., Douar, A. M., Pavirani, A., et al. (1999). Therapeutic plasma concentrations of human factor IX in mice after gene delivery into the amniotic cavity: a model for the prenatal treatment of haemophilia B. J. Gene Med. 1, 424-432.

Schneider, H., Muhle, C., Douar, A. M., Waddington, S., Jiang, Q. J., von der Mark, K., et al. (2002). Sustained delivery of therapeutic concentrations of human clotting factor IX-a comparison of adenoviral and AAV vectors administered in utero. J. Gene Med. 4, 46-53. doi: 10.1002/jgm.233

Schwartz, R. E., Reyes, M., Koodie, L., Jiang, Y., Blackstad, M., Lund, T., et al. (2002). Multipotent adult progenitor cells from bone marrow differentiate into functional hepatocyte-like cells. J. Clin. Invest. 109, 1291-1302. doi: 10.1172/JCI0215182
Sgodda, M., Aurich, H., Kleist, S., Aurich, I., Konig, S., Dollinger, M. M., et al. (2007). Hepatocyte differentiation of mesenchymal stem cells from rat peritoneal adipose tissue in vitro and in vivo. Exp. Cell Res. 313, 2875-2886. doi: 10.1016/j.yexcr.2007.05.020

Shaw, S. W., Bollini, S., Nader, K. A., Gastadello, A., Mehta, V., Filppi, E., et al. (2011a). Autologous transplantation of amniotic fluid-derived mesenchymal stem cells into sheep fetuses. Cell Transplant. 20, 1015-1031. doi: 10.3727/096368910X543402

Shaw, S. W., David, A. L., and De Coppi, P. (2011b). Clinical applications of prenatal and postnatal therapy using stem cells retrieved from amniotic fluid. Curr. Opin. Obstet. Gynecol. 23, 109-116. doi: 10.1097/GCO.0b013e32834457b1

Shi, Q., Fahs, S. A., Wilcox, D. A., Kuether, E. L., Morateck, P. A., Mareno, N., et al. (2008). Syngeneic transplantation of hematopoietic stem cells that are genetically modified to express factor VIII in platelets restores hemostasis to hemophilia A mice with preexisting FVIII immunity. Blood 112, 2713-2721. doi: 10.1182/blood-2008-02-138214

Shi, Q., and Montgomery, R. R. (2010). Platelets as delivery systems for disease treatments. Adv. Drug Deliv. Rev. 62, 1196-1203. doi: 10.1016/j.addr.2010.06.007

Shi, Q., Wilcox, D. A., Fahs, S. A., Weiler, H., Wells, C. W., Cooley, B. C., et al. (2006). Factor VIII ectopically targeted to platelets is therapeutic in hemophilia A with high-titer inhibitory antibodies. J. Clin. Invest. 116, 1974-1982. doi: 10.1172/JCI28416

Silverstein, A. M., Parshall, C. J. Jr., and Uhr, J. W. (1966). Immunologic maturation in utero: kinetics of the primary antibody response in the fetal lamb. Science 154, 1675-1677. doi: 10.1126/science.154.3757.1675

Soland, M. A., Keyes, L. R., Bayne, R., Moon, J., Porada, C. D., St Jeor, S., et al. (2014). Perivascular stromal cells as a potential reservoir of human cytomegalovirus. Am. J. Transplant. 14, 820-830. doi: 10.1111/ajt. 12642

Son, B. R., Marquez-Curtis, L. A., Kucia, M., Wysoczynski, M., Turner, A. R., Ratajczak, J., et al. (2006). Migration of bone marrow and cord blood mesenchymal stem cells in vitro is regulated by stromal-derived factor-1-CXCR4 and hepatocyte growth factor-c-met axes and involves matrix metalloproteinases. Stem Cells 24, 1254-1264. doi: 10.1634/stemcells.2005-0271

Stender, S., Murphy, M., O’Brien, T., Stengaard, C., Ulrich-Vinther, M., Soballe, K., et al. (2007). Adeno-associated viral vector transduction of human mesenchymal stem cells. Eur. Cell. Mater. 13:93-99; discussion 9.

Talens-Visconti, R., Bonora, A., Jover, R., Mirabet, V., Carbonell, F., Castell, J. V., et al. (2006). Hepatogenic differentiation of human mesenchymal stem cells from adipose tissue in comparison with bone marrow mesenchymal stem cells. World J. Gastroenterol. 12, 5834-5845.

Tarantal, A. F., Han, V. K., Cochrum, K. C., Mok, A., daSilva, M., and Matsell, D. G. (2001a). Fetal rhesus monkey model of obstructive renal dysplasia. Kidney Int. 59, 446-456. doi: 10.1046/j.1523-1755.2001.059002446.x

Tarantal, A. F., and Lee, C. C. (2010). Long-term luciferase expression monitored by bioluminescence imaging after adeno-associated virus-mediated fetal gene delivery in rhesus monkeys (Macaca mulatta). Hum. Gene Ther. 21, 143-148. doi: 10.1089/hum.2009.126

Tarantal, A. F., Lee, C. C., Jimenez, D. F., and Cherry, S. R. (2006). Fetal gene transfer using lentiviral vectors: in vivo detection of gene expression by microPET and optical imaging in fetal and infant monkeys. Hum. Gene Ther. 17, 1254-1261. doi: 10.1089/hum.2006.17.1254

Tarantal, A. F., Lee, C. I., Ekert, J. E., McDonald, R., Kohn, D. B., Plopper, C. G., et al. (2001b). Lentiviral vector gene transfer into fetal rhesus monkeys (Macaca mulatta): lung-targeting approaches. Mol. Ther. 4, 614-621. doi: $10.1006 / \mathrm{mthe} .2001 .0497$

Tarantal, A. F., McDonald, R. J., Jimenez, D. F., Lee, C. C., O'Shea, C. E., Leapley, A. C., et al. (2005). Intrapulmonary and intramyocardial gene transfer in rhesus monkeys (Macaca mulatta): safety and efficiency of HIV-1derived lentiviral vectors for fetal gene delivery. Mol. Ther. 12, 87-98. doi: 10.1016/j.ymthe.2005.01.019

Tarantal, A. F., O’Rourke, J. P., Case, S. S., Newbound, G. C., Li, J., Lee, C. I., et al. (2001c). Rhesus monkey model for fetal gene transfer: studies with retroviralbased vector systems. Mol. Ther. 3, 128-138. doi: 10.1006/mthe.2000.0255

Tasso, R., Augello, A., Carida, M., Postiglione, F., Tibiletti, M. G., Bernasconi, B., et al. (2009). Development of sarcomas in mice implanted with mesenchymal stem cells seeded onto bioscaffolds. Carcinogenesis 30, 150-157. doi: $10.1093 /$ carcin/bgn234 
Tellez, J., Finn, J. D., Tschernia, N., Almeida-Porada, G., Arruda, V. R., and Porada, C. D. (2010). Sheep harbor naturally-occurring antibodies to human AAV: a new large animal model for AAV immunology. Mol. Ther. 18(Suppl. 1), S213.

Theise, N. D., and Krause, D. S. (2002). Bone marrow to liver: the blood of Prometheus. Semin. Cell Dev. Biol. 13, 411-417. doi: $10.1016 /$ S1084952102001283

Themis, M., Schneider, H., Kiserud, T., Cook, T., Adebakin, S., Jezzard, S., et al. (1999). Successful expression of beta-galactosidase and factor IX transgenes in fetal and neonatal sheep after ultrasound-guided percutaneous adenovirus vector administration into the umbilical vein. Gene Ther. 6, 1239-1248. doi: 10.1038/sj.gt.3300970

Tiblad, E., and Westgren, M. (2008). Fetal stem-cell transplantation. Best Pract. Res. Clin. Obstet. Gynaecol.. 22, 189-201. doi: 10.1016/j.bpobgyn.2007. 07.007

Touraine, J. L. (2013). “Transplantation of human fetal liver cells into children or human fetuses," in Human Fetal Tissue Transplantation, eds N. Bhattacharya and P. Stubblefield (Berlin: Springer Verlag International), 205-18. doi: 10.1007/978-1-4471-4171-6_16

Traas, A. M., Wang, P., Ma, X., Tittiger, M., Schaller, L., O’Donnell, P., et al. (2007). Correction of clinical manifestations of canine mucopolysaccharidosis I with neonatal retroviral vector gene therapy. Mol. Ther. 15, 1423-1431. doi: 10.1038/sj.mt.6300201

Tran, N. D., Porada, C. D., Almeida-Porada, G., Glimp, H. A., Anderson, W. F., and Zanjani, E. D. (2001). Induction of stable prenatal tolerance to betagalactosidase by in utero gene transfer into preimmune sheep fetuses. Blood 97 , 3417-3423. doi: 10.1182/blood.V97.11.3417

Tran, N. D., Porada, C. D., Zhao, Y., Almeida-Porada, G., Anderson, W. F., and Zanjani, E. D. (2000). In utero transfer and expression of exogenous genes in sheep. Exp. Hematol. 28, 17-30. doi: 10.1016/S0301-472X(99) 00133-2

Troeger, C., Surbek, D., Schoberlein, A., Schatt, S., Dudler, L., Hahn, S., et al. (2006). In utero haematopoietic stem cell transplantation. Experiences in mice, sheep and humans. Swiss Med. Wkly. 136, 498-503.

Tsui, N. B., Kadir, R. A., Chan, K. C., Chi, C., Mellars, G., Tuddenham, E. G., et al. (2011). Noninvasive prenatal diagnosis of hemophilia by microfluidics digital PCR analysis of maternal plasma, D. N. A. Blood 117, 3684-3691. doi: 10.1182/ blood-2010-10-310789

Tuboly, S., Glavits, R., and Bucsek, M. (1984). Stages in the development of the ovine immune system. Zentralbl. Veterinarmed. B. 31, 81-95. doi: 10.1111/j.1439-0450.1984.tb01285.x

Van Damme, A., Chuah, M. K., Dell'accio, F., De Bari, C., Luyten, F., Collen, D., et al. (2003). Bone marrow mesenchymal cells for haemophilia A gene therapy using retroviral vectors with modified long-terminal repeats. Haemophilia 9, 94-103. doi: 10.1046/j.1365-2516.2003.00709.x

VandenDriessche, T., Vanslembrouck, V., Goovaerts, I., Zwinnen, H., Vanderhaeghen, M. L., Collen, D., et al. (1999). Long-term expression of human coagulation factor VIII and correction of hemophilia A after in vivo retroviral gene transfer in factor VIII-deficient mice. Proc. Natl. Acad. Sci. U.S.A. 96, 10379-10384. doi: 10.1073/pnas.96.18.10379

Waddington, S. N., Buckley, S. M., Nivsarkar, M., Jezzard, S., Schneider, H., Dahse, T., et al. (2003). In utero gene transfer of human factor IX to fetal mice can induce postnatal tolerance of the exogenous clotting factor. Blood 101, 1359-1366. doi: 10.1182/blood-2002-03-0779

Waddington, S. N., Nivsarkar, M. S., Mistry, A. R., Buckley, S. M., Kemball-Cook, G., Mosley, K. L., et al. (2004). Permanent phenotypic correction of hemophilia $\mathrm{B}$ in immunocompetent mice by prenatal gene therapy. Blood 104, 2714-2721. doi: 10.1182/blood-2004-02-0627

Wang, F., Dennis, J. E., Awadallah, A., Solchaga, L. A., Molter, J., Kuang, Y., et al. (2009). Transcriptional profiling of human mesenchymal stem cells transduced with reporter genes for imaging. Physiol. Genomics. 37, 23-34. doi: 10.1152/physiolgenomics.00300.2007

Weber, B., Emmert, M. Y., Behr, L., Schoenauer, R., Brokopp, C., Drogemuller, C., et al. (2012). Prenatally engineered autologous amniotic fluid stem cell-based heart valves in the fetal circulation. Biomaterials 33, 4031-4043. doi: 10.1016/j.biomaterials.2011.11.087

Xiang, J., Tang, J., Song, C., Yang, Z., Hirst, D. G., Zheng, Q. J., et al. (2009). Mesenchymal stem cells as a gene therapy carrier for treatment of fibrosarcoma. Cytotherapy 11, 516-526. doi: 10.1080/14653240902960429

Yamagami, T., Porada, C., Chamberlain, J., Zanjani, E., and Almeida-Porada, G. (2006). Alterations in host immunity following in utero transplantation of human mesenchymal stem cells (MSC). Exp. Hematol. 34(9, Suppl. 1), 39.

Zakas, P. M., Gangadharan, B., Almeida-Porada, G., Porada, C. D., Spencer, H. T., and Doering, C. B. (2012). Development and characterization of recombinant ovine coagulation factor VIII. PLOS ONE 7:e49481. doi: 10.1371/journal.pone.0049481

Zanjani, E. D., Ascensao, J. L., and Tavassoli, M. (1993). Liver-derived fetal hematopoietic stem cells selectively and preferentially home to the fetal bone marrow. Blood 81, 399-404.

Zhang, X. Y., La Russa, V. F., Bao, L., Kolls, J., Schwarzenberger, P., and Reiser, J. (2002). Lentiviral vectors for sustained transgene expression in human bone marrow-derived stromal cells. Mol. Ther. 5(5 Pt 1), 555-565. doi: 10.1006/mthe.2002.0585

Zhang, X. Y., La Russa, V. F., and Reiser, J. (2004). Transduction of bonemarrow-derived mesenchymal stem cells by using lentivirus vectors pseudotyped with modified RD114 envelope glycoproteins. J. Virol. 78, 1219-1229. doi: 10.1128/JVI.78.3.1219-1229.2004

Zhao, D. C., Lei, J. X., Chen, R., Yu, W. H., Zhang, X. M., Li, S. N., et al. (2005). Bone marrow-derived mesenchymal stem cells protect against experimental liver fibrosis in rats. World J. Gastroenterol. 11, 3431-3440.

Zheng, J. F., and Liang, L. J. (2008). Intra-portal transplantation of bone marrow stromal cells ameliorates liver fibrosis in mice. Hepatobiliary Pancreat. Dis. Int. 7, 264-270.

Zuk, P. A., Zhu, M., Ashjian, P., De Ugarte, D. A., Huang, J. I., Mizuno, H., et al. (2002). Human adipose tissue is a source of multipotent stem cells. Mol. Biol. Cell 13, 4279-4295. doi: 10.1091/mbc.E02-02-0105

Zuk, P. A., Zhu, M., Mizuno, H., Huang, J., Futrell, J. W., Katz, A. J., et al. (2001). Multilineage cells from human adipose tissue: implications for cell-based therapies. Tissue Eng. 7, 211-228. doi: 10.1089/1076327013000 62859

Conflict of Interest Statement: The authors declare that the research was conducted in the absence of any commercial or financial relationships that could be construed as a potential conflict of interest.

Received: 08 October 2014; accepted: 27 November 2014; published online: 11 December 2014.

Citation: Porada CD, Rodman C, Ignacio G, Atala A and Almeida-Porada G (2014) Hemophilia A: an ideal disease to correct in utero. Front. Pharmacol. 5:276. doi: 10.3389/fphar.2014.00276

This article was submitted to Integrative and Regenerative Pharmacology, a section of the journal Frontiers in Pharmacology.

Copyright (c) 2014 Porada, Rodman, Ignacio, Atala and Almeida-Porada. This is an open-access article distributed under the terms of the Creative Commons Attribution License (CC BY). The use, distribution or reproduction in other forums is permitted, provided the original author(s) or licensor are credited and that the original publication in this journal is cited, in accordance with accepted academic practice. No use, distribution or reproduction is permitted which does not comply with these terms. 